Journal of Clinical Investigation
Vol. 42, No. 6,1963

\title{
CELL PROLIFERATION KINETICS IN THE GASTROINTESTINAL TRACT OF MAN. I. CELL RENEWAL IN COLON AND RECTUM *
}

\author{
By MARTIN LIPKIN, BERTRAND BELL, AND PAUL SHERLOCK \\ (From the Department of Medicine, Cornell University Medical College, Second [Cornell] \\ Medical Division, Bellevue Hospital, and the Department of Medicine, Sloan- \\ Kettering Institute for Cancer Research, New York, N. Y.)
}

(Submitted for publication August 27, 1962; accepted February 13, 1963)

In studies of cell proliferation in the intestine of animals during the past few years, observations have been made that suggest points of interest concerning cell renewal in humans. In rodents, proliferating jejunal and colonic epithelial cells have mean generation times of about 12 to 18 hours, DNA synthesis ( $S$ phase) times of 5 to 8 hours, and premitosis $\left(G_{2}\right)$ and mitosis $(M)$ times of 1 to 2 hours (1-3). Also, although many epithelial cells undergo a second generation cycle soon after mitosis, some cells appear to remain longer in interphase before dividing again (3). The rate of disappearance of labeled cells from the mucosa has also been shown to vary in different portions of the gastrointestinal tract in a number of species; e.g., more labeled cells are present in the colon and stomach 1 week after injection of $\mathrm{H}^{3}$-thymidine than in the duodenum or jejunum (4).

In man, studies of mitotic indexes and radioautographic studies with $\mathrm{H}^{3}$-thymidine have suggested turnover times of intestinal epithelial cells in the order of several days (5-7). In the present study, we have measured the mean generation time and the phases of the proliferative cycle of human colonic and rectal epithelial cells after the administration of $\mathrm{H}^{3}$-thymidine. The results describe cell renewal and give data on the rate of disappearance of labeled cells from the mucosa of the human colon and rectum.

\section{METHODS}

Two patients with colostomies were studied. Both had resections of the descending colon for carcinoma of the rectum and liver metastases. The colostomies were composed of normal mucosa of the transverse colon. A

* Supported in part by U. S. Public Health Service grants A-3165 and C-3697, and by The John A. Hartford Foundation, Inc., New York, N. Y. third patient with a carcinoma of the rectum $8 \mathrm{~cm}$ proximal to the anal orifice was studied. Although all patients had carcinoma and known metastases, and had recently lost weight, they were fairly well-nourished at the time of these studies.

Patient 1, a 61-year-old woman, was given intravenously $0.26 \mu \mathrm{c}$ per $\mathrm{g}$ of $\mathrm{H}^{3}$-thymidine; Patient 2, a 53-year-old man, $0.05 \mu \mathrm{c}$ per $\mathrm{g}$; and Patient 3, a 91-year-old man, $0.02 \mu \mathrm{c}$ per $\mathrm{g}$ (SA $6.59 \mathrm{c}$ per mmole dissolved in $10 \mathrm{ml}$ of water). After the injection of thymidine, serial biopsies of the mucosa were taken from the surface of the colostomies to a point $5 \mathrm{~cm}$ proximal to the stoma. Normal rectal mucosa $4 \mathrm{~cm}$ from the anal orifice and $4 \mathrm{~cm}$ distal to the carcinoma was also biopsied. Two to four specimens were taken at each period, and data were pooled for analysis. Specimens were removed from 15 minutes to 12 weeks after injection of $\mathrm{H}^{3}$-thymidine, fixed in neutral formol-saline, embedded in paraffin, and sectioned at $4 \mu$. For microradioautography, slides were dipped in Kodak NTB liquid emulsion, exposed for 2 to 3 months, developed, and stained with hematoxylin and eosin.

Distribution of labeled cells was studied in the crypt cell column, which was situated in one optical plane and extended from the bottom to the mouth of the crypt. In recording the position of each cell in the crypt cell column, the cell at the bottom of the crypt occupied position 1 , the next cell towards the mouth of the crypt position 2 , and so on. The following measurements were made: 1 ) position of labeled epithelial cells in the colonic and rectal crypts, 2) counts of labeled and unlabeled mitoses at various intervals after labeling, 3 ) rate of removal of labeled epithelial cells from the colonic mucosa, and 4) rate of decrease of label in individual epithelial cells. Methods of data analysis for 1 and 2 have been previously described $(1,3)$.

\section{RESULTS}

Representative microradioautographs prepared from specimens taken from Patient 1 at periods 2 hours and 8 days after injection of $\mathrm{H}^{3}$-thymidine are shown in Figure 1. The zone of rapid epithelial cell proliferation is located in the lower and middle third of the colonic crypts. In Figure $1 \mathrm{~A}$, labeled proliferating cells are seen blended 

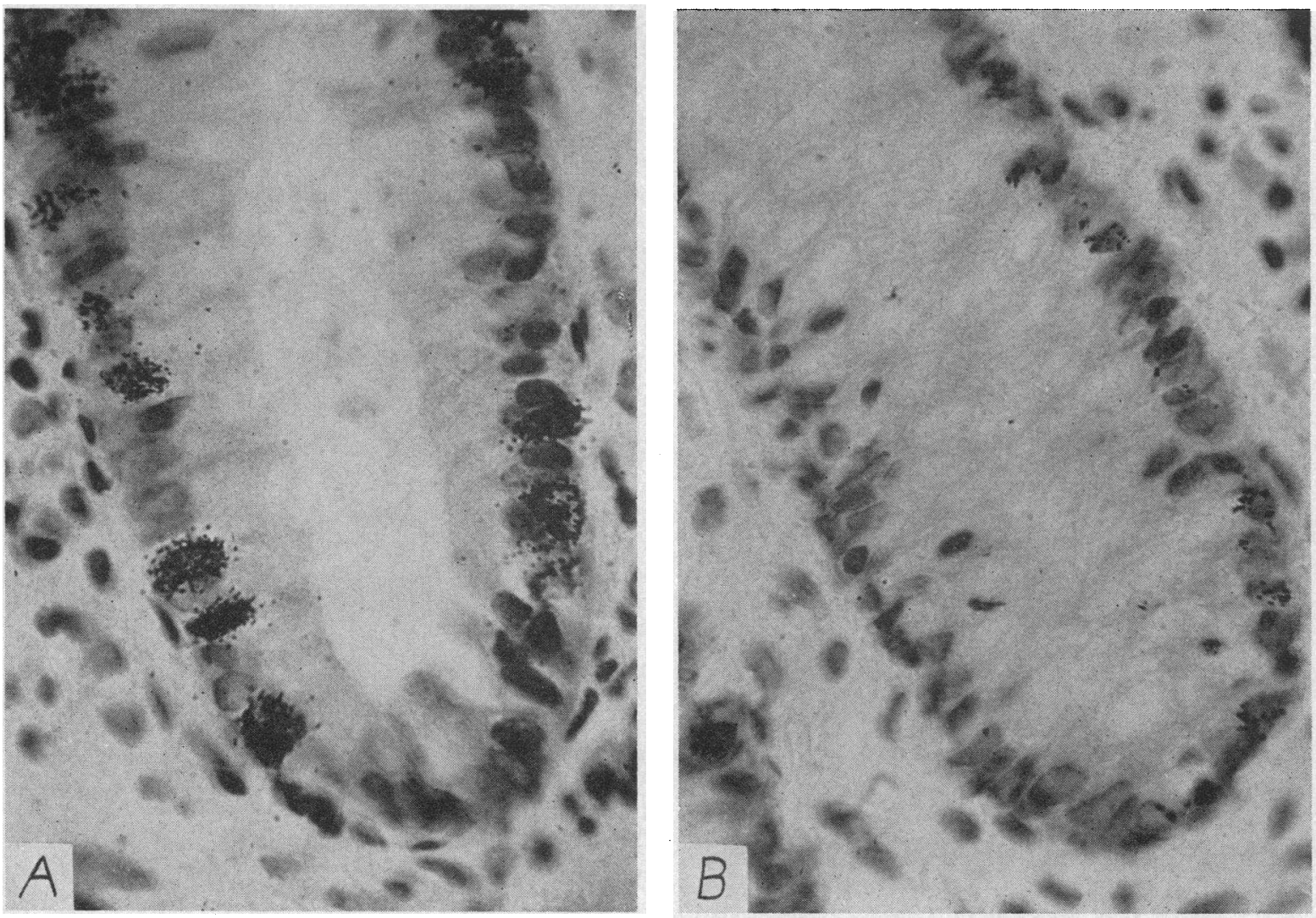

Fig. 1. LABeled, NEWLy SYNTHESIZEd DNA IN EPITHELIAL CELlS SEEN IN MiCRORADIOAUTOGRAPHS OF LOWER PORTION OF HUMAN colonic CRYPT. A. 2 hours, and B. 8 days after injection of $\mathrm{H}^{3}$-thymidine. Hematoxylin and eosin stain; $\times 800$.

with some nonproliferating and mature cells. In Figure 1B, labeled cells remain with fewer grains per cell. The distribution of labeled cells in the crypts of the human colon is similar to that seen in other species $(3,4)$.

Duration of the phases of the proliferative cycle. Phases of the proliferative cell cycle are outlined in Figure 2. DNA synthesis occurs primarily in a portion of interphase called the $S$ (synthesis) phase, which divides the interphase into the $\mathrm{G}_{1}$ phase (postmitotic, presynthetic "gap") and the $G_{2}$ phase (postsynthetic, premitotic "gap"). In order, phases $M$ (mitotic), $G_{1}, S$, and $\mathrm{G}_{2}$ constitute the complete cycle.

$\mathrm{H}^{3}$-thymidine is incorporated into DNA during the $S$ phase and thereby labels the cell nucleus at a specific time in its life cycle. Since decaying tritium atoms emit beta rays with a penetrating range of about $1 \mu$, the photographic grains acti- vated by the beta rays define the position of the labeled cell.

Figure 3A shows the fraction of mitoses labeled at various times after the injection of $\mathrm{H}^{3}$ thymidine in the colonic mucosa of Patient 1 . The number of mitoses at each point ranges from 7 to 58 , with a mean of 27.4 , within $95 \%$ confidence limits (vertical bars). In Figure 3A, although many labeled cells are seen at 2 hours, almost no labeled mitoses are present. This period represents the minimal duration of the $G_{2}$ phase of the proliferative cycle.

Mitoses derived from cells leaving the $\mathrm{S}$ phase at the time of injection are recorded in the earliest part of the ascending wave of labeled mitoses, and those from cells entering the $S$ phase at the time of injection are recorded in the descending part of the wave. After slightly more than 2 hours, $50 \%$ of mitoses were labeled, as shown in Figure 


\section{$M$ Mitosis \\ G) Interval between mitosis and DNA synthesis \\ $S$ DNA synthesis \\ $G_{2}$ Interval between DNA synthesis and mitosis}

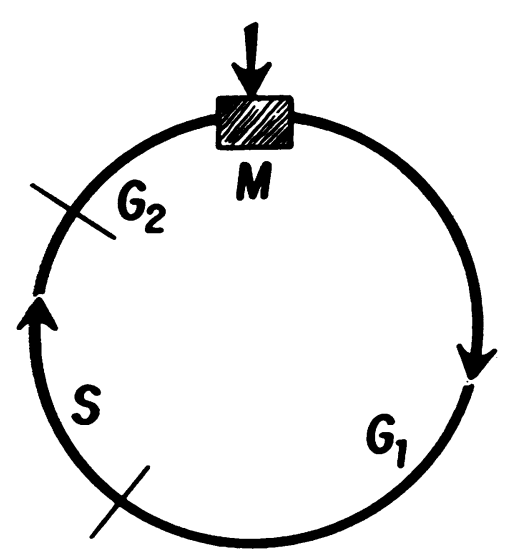

Fig. 2. Phases of Proliferative cycle.

3A. This is approximately the mean duration of $G_{2}$ plus about half $M$. The fraction of labeled mitoses rose rapidly to about 0.92 . The mid-point of the subsequent decline in the wave of labeled mitoses occurred at 17 hours. The mean duration of the $\mathrm{S}$ phase is measured as the distance between the mid-points of the rise and fall of the wave of labeled mitoses, and this is close to 15 hours. Labeled mitoses are fewest at 20 to 24 hours. This trough contains cells in $G_{1}, M$, and $G_{2}$ phases at the time of injection; these cells are unlabeled, since labeling occurs during the $S$ phase. The minimal duration of the proliferative cycle can be estimated by the addition of the duration of the $G_{1}$ phase to the known durations of the other phases of the cycle; from the wave of labeled mitoses, the total time appears to be at least 1 day.

Figure $3 \mathrm{~B}$ shows the fraction of mitoses labeled at various times after $\mathrm{H}^{3}$-thymidine in the colonic mucosa of Patient 2. The number of mitoses at each point was 8 to 93 , with a mean of 37.2. Practically all mitoses were unlabeled 15 minutes after $\mathrm{H}^{3}$-thymidine, and this is the minimal duration of phase $G_{2}$ in Patient 2. $G_{2}$ plus $0.5 \mathrm{M}$ lasts about 1.5 hours. The wave of labeled mitoses reached a peak of 0.92 at about 6 to 8 hours and then declined. The interval between the mid-points of the rise and fall, the $\mathrm{S}$ phase, is 11 to 14 hours. From these measurements, the entire proliferative cycle would also be about 1 day.

Figure $3 \mathrm{C}$ shows the fraction of mitoses labeled in the crypts of the rectal mucosa in Patient 3. The number of mitoses counted at each point here was 6 to 40, with a mean of 29.8. Labeled mitoses began to appear within 2 hours after injection of $\mathrm{H}^{3}$-thymidine, and the minimal duration of phase $\mathrm{G}_{2}$ is less than 2 hours. The wave of labeled mitoses rose within 4 hours to a peak of 0.95 and then declined. The interval between the midpoints of rise and fall, the $S$ phase, is 10 to 12 hours. Labeled mitoses were fewest after 16 hours, and the minimal proliferative cycle also appears to be about 1 day. Table $I$ enumerates the durations of phases $G_{2}, S$, and $M$.

Direct measurement of the rate of increase of labeled cells. Figure 4A shows the fraction of cells at each position that are labeled $\frac{1}{2}$ hour (i.e.. before labeled cells divide) and 24 hours after labeling in Patient 1; Figure 4B shows them $\frac{1}{2}$ and 29 hours after labeling in Patient 2; and Figure 4 C, 1 and 16 hours after labeling in Patient 3 . The distribution of labeled cells in the colonic and rectal crypts is shown as cells divide and migrate toward the crypt surfaces during these periods.

Cell proliferation takes place in the lower and middle third of the crypt, an area termed the "proliferation compartment"; its approximate boundaries are seen at 0.5 to 1 hour in Figure 4, between the labeled cell in the lowest cell position and the dotted line. The boundaries are not exact because scattered labeled cells could appear slightly higher or lower in the crypts. The lowest positions characteristically contain very few labeled cells. In the crypts of the colon and rectum. proliferating cells mingle with nonproliferating

TABLE I

Duration of phases of the proliferative cycle*

\begin{tabular}{llll}
\hline \hline \multirow{2}{*}{$\begin{array}{c}\text { Phase of } \\
\text { proliferative cycle }\end{array}$} & \multicolumn{3}{c}{ Duration } \\
\cline { 2 - 4 } & Patient 1 & Patient 2 & Patient 3 \\
\hline & \multicolumn{1}{c}{ hours } & \multicolumn{1}{c}{ hours } & \multicolumn{1}{c}{ hours } \\
$\mathrm{G}_{2}$, minimum & 2 & 0.25 & 2 \\
$\mathrm{G}_{2}+0.5 \mathrm{M}$ & 2 to 2.5 & 1 to 1.5 & 2 to 3 \\
$\mathrm{~S}$ & 15 & 11 to 14 & 10 to 12
\end{tabular}

* Phases described in Figure 2. 

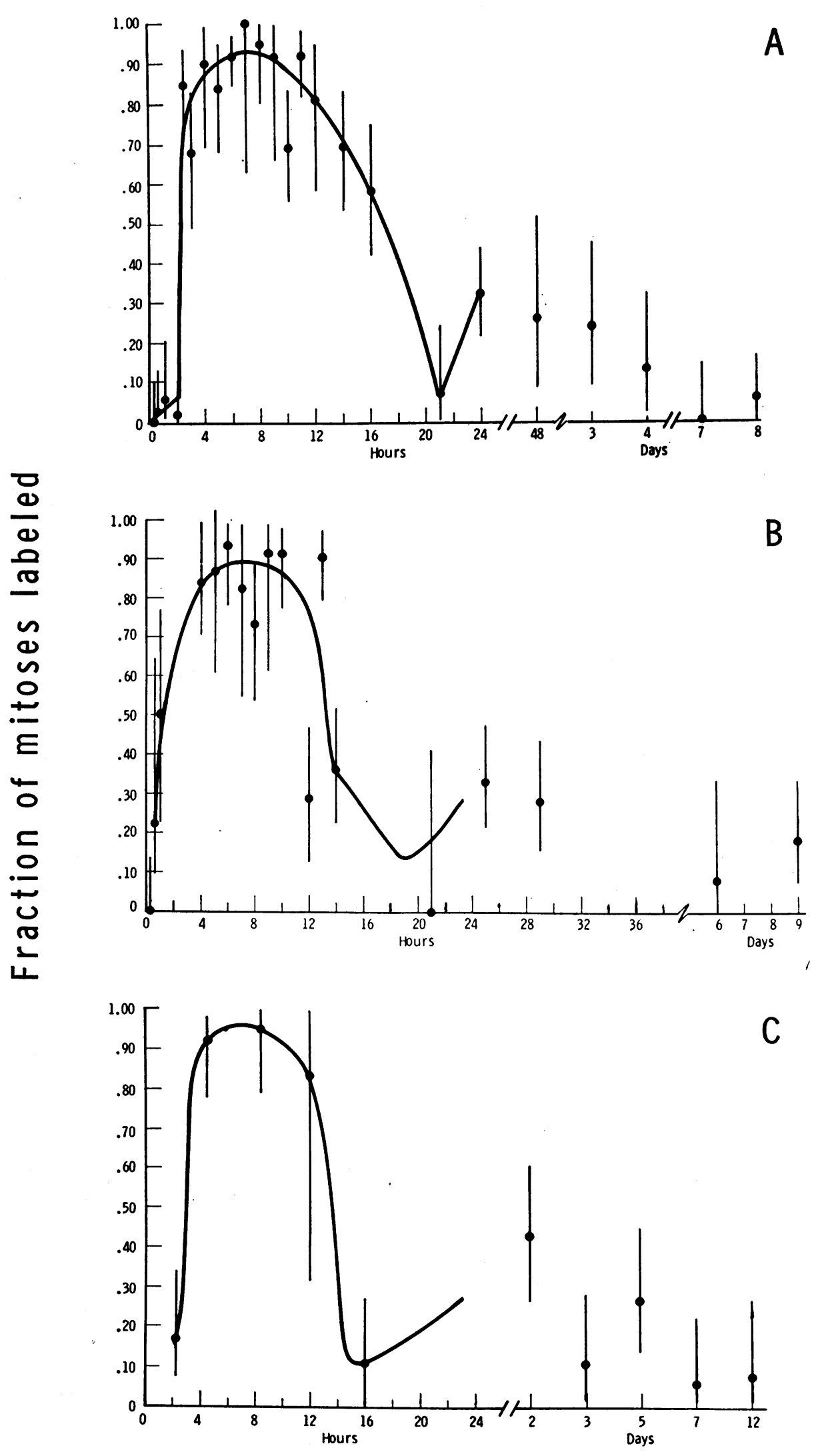

Time between labeling and biopsy

FIg. 3. 


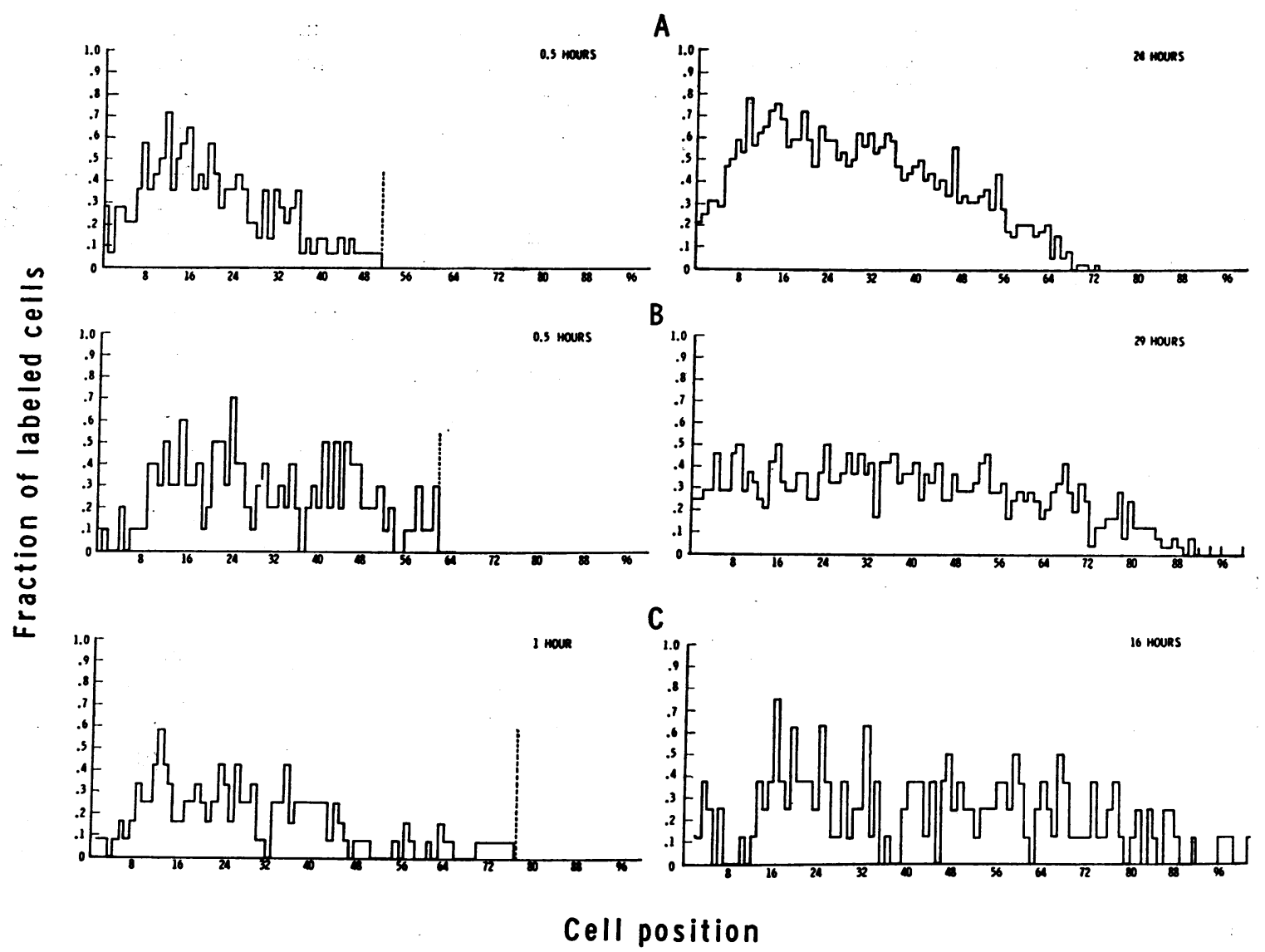

Fig. 4. Fraction of cells labeled at each position in CRypts of human colon and Rectum. A. Patient 1 , colon, 0.5 and 24 hours after labeling. B. Patient 2 , colon, 0.5 and 29 hours after labeling. C. Patient 3, rectum, 1 and 16 hours after labeling. Position 1 is that of cell at bottom of crypt, position 2 is that of next cell toward crypt surface, and so on. An increase in labeled cells at each position and movement toward the crypt surfaces is seen at later periods.

and mature cells. Above the proliferation compartment, mature cells migrate to the crypt surfaces and are extruded into the lumen of the colon.

Counts of labeled and unlabeled cells are shown in Table II. Notation is as follows: $N=$ number of cells in the crypt cell column, $\mathrm{N}_{\mathrm{s}}=$ number of cells in the $S$ phase, $T_{s}=$ duration of the $S$ phase, $\mathrm{N}_{\mathrm{d}}=$ position of the most distal labeled cell before appearance of labeled mitoses, $\mathrm{K}_{\mathrm{b}}=$ prolifer-

Fig. 3. Fraction of mitoses Labeled at various TIMES BETWEEN LABELING AND BIOPSY, IN: EPITHELIAL Cells of human colon and. Rectum. A. Patient 1, colon. B. Patient 2, colon. C. Patient 3, rectum. Each point represents pooled data from 2 to 4 biopsy specimens at the same period. Vertical bars show . $95 \%$ confidence limits. The line is fitted by eye through the mean values. ative rate (cells per 100 cells per hour), $N_{c}=$ number of cells in the proliferative cycle, and $T_{c}$ $=$ time of proliferative cycle in hours. In Patient 1 , counts of labeled and unlabeled cells gave a mean $\mathrm{N}$ of 85 cells, including cells that have reached the crypt surfaces. In each crypt cell column, mean $\mathrm{N}_{\mathrm{s}}$ was 14 cells $\frac{1}{2}$ to 1 hour after injection of $\mathrm{H}^{3}$-thymidine; subsequent division of labeled cells increased their number. $T_{\mathbf{s}}$ is obtained from the counts of labeled mitoses (Figure 3 ). $N_{d}$ defines the approximate upper boundary of the proliferation compartment at cell position 51.

Proliferative and migratory rates derived from counts of labeled and unlabeled cells are shown in Table III. In all three patients, the fraction of cells labeled in the entire crypt cell column, $\mathrm{N}_{\mathrm{s}} / \mathrm{N}$, 
TABLE II

Counts of labeled and unlabeled cells

\begin{tabular}{llll}
\hline \hline & Patient 1 & Patient 2 & Patient 3 \\
\hline $\begin{array}{l}\text { Number of cells in crypt } \\
\text { cell column, N }\end{array}$ & $85 \pm 2.4$ SE & $92 \pm 2.8 \mathrm{SE}$ & $106 \pm 2.2 \mathrm{SE}$ \\
$\begin{array}{c}\text { Number of cells per crypt } \\
\text { column in phase of DNA } \\
\text { synthesis, Ns }\end{array}$ & $14 \pm 1.4 \mathrm{SE}$ & $16.1 \pm 1.1 \mathrm{SE}$ & $12 \pm 0.5 \mathrm{SE}$ \\
$\begin{array}{c}\text { Number of cells per crypt } \\
\text { column labeled at later } \\
\text { times: } \\
\text { 16 hours }\end{array}$ & $31 \pm 1.6 \mathrm{SE}$ & $27 \pm 1.7 \mathrm{SE}$ & \\
$\quad \begin{array}{l}\text { 24 hours } \\
\text { 29 hours }\end{array}$ & 14 & 14 & 11 \\
$\begin{array}{l}\text { Duration of synthesis } \\
\text { phase, Ts }\end{array}$ & 51 & 62 & 76 \\
$\begin{array}{c}\text { Position of most distal } \\
\text { labeled cell, Nd }\end{array}$ & & & \\
\hline
\end{tabular}

ranges from 0.17 to 0.12 . (About 60 to $72 \%$ of the cells of the proliferation compartment are labeled.) Within the cell population, $\mathrm{N}_{\mathrm{s}} / \mathrm{T}_{\mathbf{s}}$ is equal to the ratio of the number of cells in the proliferative cycle to the cycle time, $\mathrm{N}_{\mathrm{c}} / \mathrm{T}_{\mathrm{c}}$. In all three patients, $\mathrm{N}_{\mathrm{S}} / \mathrm{T}_{\mathrm{S}}$ is 1.0 to 1.1 . The proliferative or birth rate is therefore 1 to 1.1 cells per crypt column per hour. Thus, in Patient 1, 14 cells in the crypt column enter the $S$ phase for 14 hours, equivalent to 1 cell entering the $S$ phase per hour and 1 cell per crypt column per hour. The turnover rate is also 1 to 1.1 cells per crypt column per hour. Since the fraction of labeled crypt cells is 0.17 in Patient $1, K_{b}$ is $17 / 14$ or 1.2 cells per 100 cells per hour.

The migratory or death rate can be estimated from the movement of cells seen in Figure 4. In

TABLE III

Proliferative and migratory rates

\begin{tabular}{|c|c|c|c|}
\hline & Patient 1 & Patient 2 & Patient 3 \\
\hline $\begin{array}{l}\text { Fraction of cells labeled } \\
\text { in crypt cell column } \\
\text { (labeling index), } \\
\mathrm{N}_{\mathrm{g}} / \mathrm{N}\end{array}$ & 0.17 & 0.18 & 0.12 \\
\hline $\begin{array}{l}\text { Approximate fraction of } \\
\text { cells labeled in pro- } \\
\text { liferation compart- } \\
\text { ment, } N_{B} / N_{d}\end{array}$ & 0.60 & 0.67 & 0.72 \\
\hline $\begin{array}{l}\text { Proliferative rate in: } \\
\text { cells per crypt column } \\
\text { per hour }\end{array}$ & 1.0 & 1.1 & 1.1 \\
\hline $\begin{array}{l}\text { cells per } 100 \text { cells per } \\
\text { hour, } K_{b}\end{array}$ & 1.2 & 1.3 & 1.1 \\
\hline $\begin{array}{l}\text { Time of proliferative } \\
\text { cycle, in days }\end{array}$ & $\frac{3}{4}$ to 2 & & \\
\hline
\end{tabular}

Patient 1, labeled cells moved from about position 50 to 70 in 23.5 hours, for a flow or migratory rate of 0.87 cell positions per hour. In patient 2 , they moved from about position 65 to 90 in 28.5 hours, for a migratory rate of 0.91 cell positions per hour. Estimates of birth rate are slightly higher than those of migratory and death rate. This difference could be due to variation inherent in the determination, or to a few cell deaths and lack of migration of these cells to the crypt surface.

A minimal estimate of $T_{c}$ can be obtained from the wave of labeled mitoses, Figure 3. Phases $\mathrm{S}$, $G_{2}$, and $M$ last at least 14 to 16 hours, so the mean $T_{c}$ with $G_{1}$ added is longer than this. More accurate measurement cannot be made because $\mathrm{N}_{\mathrm{c}}$ is not known, but a reasonable estimate can be given.

The zone of heaviest labeling in Patient 1 occurs between cell positions 2 and 36 (Figure 4A). Since $N_{s} / T_{s}=N_{c} / T_{c}$, if no mature cells were present in this area, $14 / 14=34 / T_{c}$, and $T_{c}$ would be 34 hours. With mature cells present, $N_{c}$ is

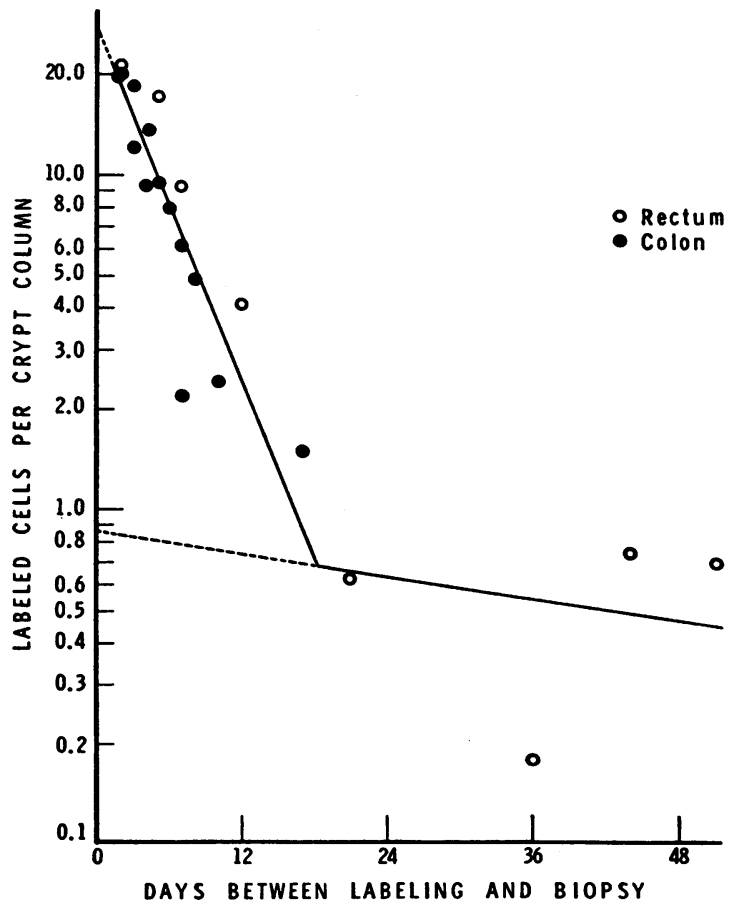

Fig. 5. Rate of Removal of Labeled Cells from CRYPTS OF HUMAN COLON AND RECTUM. The number of labeled cells per crypt decreases after 1 day. Most cells are rapidly removed; half-life $=2$ to 3 days. A few labeled epithelial cells remain after 3 weeks and are removed more slowly. 
less than 34 , and $T_{c}$ is also lower. The mean $T_{c}$ must therefore be in the order of 1 day.

Rate of removal of labeled cells. Figure 5 shows the rate of removal of labeled cells in colon and rectum. Six to 27 crypts (mean 13.5) were studied at each period. For the first day, the number of labeled cells per crypt column increased. Labeled cells then reached the mouths of the crypts, began to slough into the lumen, and after 1 to 2 days, the number of labeled cells per crypt column decreased. The half-life of the fall-off curve of the colon and rectum is about 2 to 3 days. After removal of most cells, a slower component is also seen, with a half-life in the order of several weeks. The presence of a few heavily labeled cells several weeks after injection of $\mathrm{H}^{3}$-thymidine is confirmed in the data that follow.

Distribution of grains over individual cells. The rate of decrease of label in individual cells of $\mathrm{Pa}$ tient 1 is shown in Figures 6 and 7. Fourteen crypt columns were studied at each period. Distribution of grains at 4 periods in Patient 1 is shown in Figure 6. One hour after injection of $\mathrm{H}^{3}$-thymidine, most labeled cells contain more than 40 grains per cell, with a few scattered cells containing 10 to 40 . After 48 hours, the number of cells with over 40 grains has been halved and more contain 5 to 37 grains per cell. At this time, $50 \%$ fewer cells in the crypt columns are unlabeled. The fact that labeled cells do not contain 1 to 5 grains at the early periods indicates

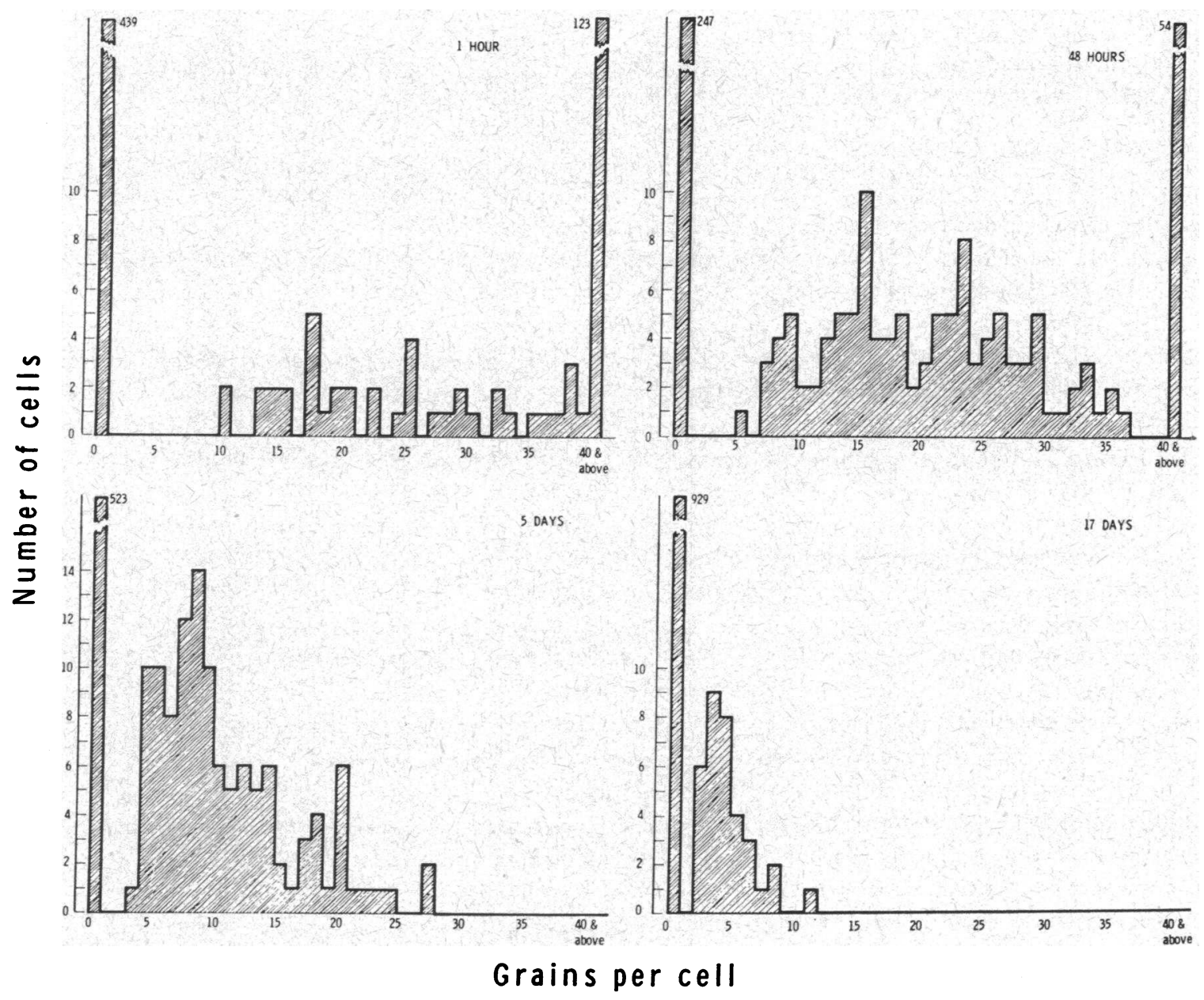

Fig. 6. Distribution of grains in individual colonic epithelial cells in Patient 1. One hour after labeling, most cells contain over $\mathbf{4 0}$ grains. At later periods, the grain density in individual cells decreases. 


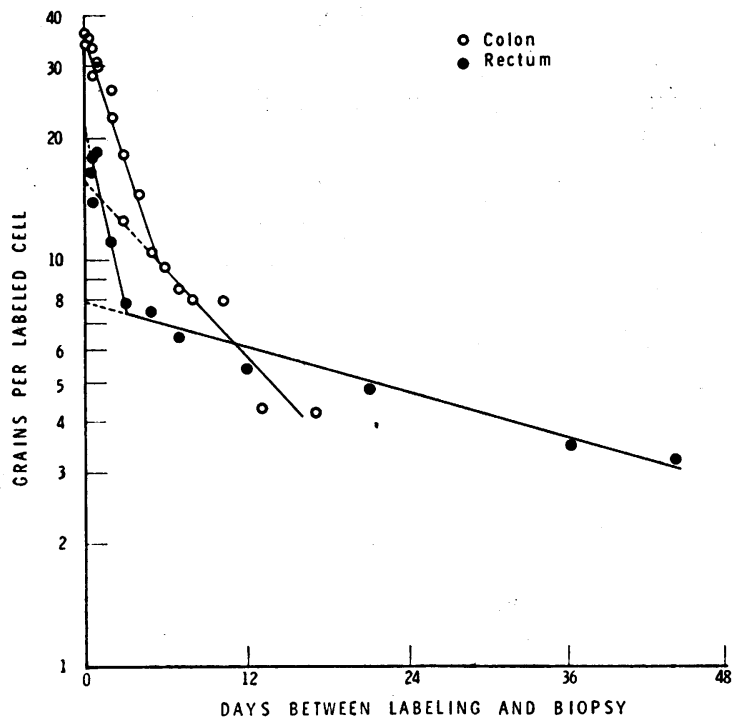

Fig. 7. MEAN Number of grains Per Labeled Cell AT VARIOUS TIMES BETWEEN LABELING AND BIOPSY. The mean number declines rapidly; half-life $=1$ to 2 days. After 3 to 5 days, the number declines slowly in the remaining labeled cells; half-life $=8$ days or more.

that the presence of "false negatives" (i.e., cells that contain labeled DNA, but do not register grains because of nuclear sectioning, or exposure time) is minimal. After $\mathbf{5}$ days, all labeled cells contain 3 to 27 grains per cell, and after 17 days, most cells are unlabeled, with 2 to 12 grains distributed over a few scattered cells.

In Figure 7, the mean number of grains per cell is plotted at each period. The number declines rapidly to 3 to 5 days, with a half-life of about 1.5 days, in approximate agreement with the estimated mean $T_{c}$. Thereafter, the number of grains per cell declines more slowly, with a halflife of about 8 days or longer. Heavily labeled cells thus divide rapidly, dilute their label, migrate, and are extruded from the crypt surfaces. After 3 to 5 days, it is possible to observe a few cells ( 5 to 8 per crypt column, Figure 5 ) that do not dilute their label, and some of these cells remain within the crypts for as long as several months. It would appear that these cells are eventually extruded, or dilute their label to background level. Retention of heavily labeled cells in the colon has been observed in a number of species $(3,4,8)$, and questions related to their origin and possible significance are of great interest.

\section{DISCUSSION}

Proliferative cycle. The measurements in colon and rectum reveal a $T_{c}$ of about 1 day, divided into an $S$ phase lasting 11 to 15 hours, a $G_{2}$ phase that, combined with mitosis, lasts 1 to 3 hours, and a $\mathrm{G}_{1}$ phase, not precisely measured. $\mathrm{G}_{2}$ and $\mathrm{S}$ phases are longer in man than in rodents. In the latter, variations have been most pronounced for the duration of $\mathrm{G}_{1}$.

The $S$ phase in Patient 1 is close to 15 hours; a second study of her, to be reported later, revealed an $\mathrm{S}$ phase of identical duration. In $\mathrm{Pa}$ tient 2 , the $\mathrm{S}$ phase is 11 to 14 hours, and in $\mathrm{Pa}$ tient 3,10 to 12 hours. Slight differences are within the range of variation for the determination, and could also be due to differences in area of mucosa, or among patients, including age and other factors.

Crypt replacement. In the specimens studied here, mean values are as follows. $\mathrm{N}$ is 95 cells; of these, $\mathrm{N}_{\mathrm{s}}$ is 14 cells $(15 \%) . \quad \mathrm{K}_{\mathrm{b}}$ is 1.2 cells per 100 cells per hour. Since $N$ ranges from 85 to 105 cells, they are replaced in about 3 to 4 days. The measured migratory and death rate of the cells appears to be slightly less than $K_{b}$, and it may be that a few cells do not migrate to the crypt surfaces or die shortly after birth.

The patients studied here all had carcinoma. The possible influence of carcinoma on cell renewal is not now known. Although these patients were adequately nourished, they had all lost weight. Also, they all had liver metastases. The similarity, however, of the measurements in man to measurements in rodents (1-3) led us to believe that those in man are probably close to those that would be found in healthy adults. Detailed analysis of the variations present in individuals and of the influence of age, sex, and disease on cell renewal has not been made in man.

Prolonged retentian of labeled cells. After intravenous injection of $\mathrm{H}^{3}$-thymidine into humans, plasma is rapidly cleared during the first passage through the capillary bed, with about $50 \%$ of the administered $\mathrm{H}^{3}$-thymidine catabolized to tritiated water in $\frac{1}{2}$ hour (9). Labeling of proliferative cells of the bone marrow and intestine is nearly complete within a few minutes after injection of $\mathrm{H}^{3}$-thymidine $(1,9)$, which is incorporated inte DNA synthesized at the time of labeling, with 
negligible partition of radioactivity into RNA or other components (10). Although DNA may not be completely inactive metabolically, the amounts of thymidine entering into such metabolic activity are small compared to the amounts incorporated during DNA doubling; similarly, the dilution of DNA during successive cell divisions should occur much faster than dilution due to metabolic activity (1). Our patients did not have urinary abnormalities and had normal values of blood urea nitrogen. We conclude that the measurements of cell proliferation made after injection of $\mathrm{H}^{3}$-thymidine should not be subject to error due to availability of thymidine after initial incorporation.

Measurements of the rate of removal of labeled cells, however, are subject to a number of modifying factors. In the proliferative cycle of many cell types, the $G_{1}$ phase is believed to be very variable. It is also known that daughter cells in tissue culture media characteristically have duplication times that may differ markedly from each other and from the mother cell (11). It is therefore not surprising that a few heavily labeled cells remain in the mucosa longer than most. Besides these factors favoring the retention of labeled cells, labeled material from desquamated cells is available for reincorporation into newly formed cells 3 days after the injection of $\mathrm{H}^{3}$ thymidine (12-15). Labeled nucleotide fragments of DNA could participate in this reincorporation. The rate of removal of the labeled cells remaining at later periods is therefore likely to be affected by prolonged interphase and also by reincorporation of labeled fragments of DNA. Reincorporation of label is a continuous feeding process over a finite period, as labeled cells desquamate, and the reincorporated label is therefore fairly diffusely spread within the newly proliferating cells. This is not, however, the labeling pattern seen in these microradioautographs, where isolated, heavily labeled cells are seen at later times, suggesting that the major factor in their origin is prolonged interphase.

The presence of a few heavily labeled cells in the crypts of the colon, after the label in most cells has been reduced to background level, has been previously seen in other species $(3,8)$. Thus, in the mouse, although the mean $T_{c}$ is similar in small and large intestine, a few heavily labeled cells remain in the colon longer than in the duodenum or jejunum. The retention of labeled cells in specific areas of the gastrointestinal tract, including stomach and colon, in a number of species correlates with the occurrence of precancerous and cancerous lesions in the same areas of the gastrointestinal tract of man (4). The influence of various factors on the distribution of the labeled cells remaining in the mucosa for extended periods and their possible significance are currently under investigation.

\section{SUM MARY}

In order to begin a comparison of cell renewal in different parts of the human gastrointestinal tract and to evaluate possible relationships between cell renewal and disease states, estimates were made of the mean proliferative time and the phases of the proliferative cycle of colonic and rectal epithelial cells. The rate of reduction of label in individual cells and the rate of removal of cells from the mucosa were also measured.

After injection of $\mathrm{H}^{3}$-thymidine, the mean proliferative time of epithelial cells of colon and rectum was found to be about 1 day, divided into a phase of DNA synthesis lasting 11 to 15 hours, a postsynthetic, premitotic phase that, combined with mitosis, lasts 1 to 2 hours, and a postmitotic, presynthetic phase of 10 to 30 hours. About 15\% of the crypt cells are in the synthesis phase. Cell renewal proceeds at a mean rate of 1.2 cells per 100 cells per hour, and the entire colonic and rectal crypts are replaced in about 3 to 4 days. Labeled cells migrate at a rate of about 0.9 cell positions per hour. The area of cell proliferation occupies about $65 \%$ of the colonic and rectal crypt columns.

After labeling, the mean number of grains per labeled cell declines rapidly (half-life $=1$ to 2 days), and labeled cells are rapidly removed from the mucosa. A few labeled cells, however, remain in the crypts after the label in most cells has been reduced to background level. Although reincorporation of labeled fragments from desquamated cells occurs, it is likely that large differences in the duration of interphase contribute to slow cell division and retention of a few labeled cells. Further studies are needed to measure the variability of interphase in cell populations of the gastrointestinal tract in man. 


\section{ACKNOWLEDGMENT}

We thank Miss Geraldine Kraska, Mr. Jay Rubin, Mrs. Eileen Kairys, and Mr. Paul Frenkel for assistance in carrying out this study.

\section{REFERENCES}

1. Quastler, H., and F. G. Sherman. Cell population kinetics in the intestinal epithelium of the mouse. Exp. Cell Res. 1959, 17, 420.

2. Lesher, S., R. J. M. Fry, and H. I. Kohn. Age and generation time of the mouse duodenal epithelial cell. Exp. Cell Res. 1961, 24, 334.

3. Lipkin, M., and H. Quastler. Cell population kinetics in the colon of the mouse. J. clin. Invest. 1962, $41,141$.

4. Lipkin, M., and H. Quastler. Cell retention and incidence of carcinoma in several portions of the gastrointestinal tract. Nature (Lond.) 1962, 194, 1198.

5. Cole, J. W., and A. McKalen. Observations of cell renewal in human rectal mucosa in vivo with thymidine- $\mathrm{H}^{3}$. Gastroenterology 1961, 41, 122.

6. Bertalanffy, F. D., and K. P. Nagy. Mitotic activity and renewal rate of the epithelial cells of the human duodenum. Acta anat. (Basel) 1961, 45, 362.

7. Lipkin, M., P. Sherlock, and B. M. Bell. Generation time of epithelial cells in the human colon. Nature (Lond.) 1962, 195, 175.
8. Messier, M., and C. P. Leblond. Cell proliferation and migration as revealed by radioautography after injection of thymidine- $\mathrm{H}^{3}$ into male rats and mice. Amer. J. Anat. 1960, 106, 247.

9. Rubini, J. R., E. P. Cronkite, V. P. Bond, and T. M. Fliedner. The metabolism and fate of tritiated thymidine in man. J. clin. Invest. 1960, 39, 909.

10. Friedkin, M., D. Tilson, and D. Roberts. Studies of deoxyribonucleic acid biosynthesis in embryonic tissues with thymidine-C ${ }^{14}$. J. biol. Chem. 1956, 220, 627.

11. Kubitschek, H. E. Discrete distributions of generation-rate. Nature (Lond.) 1962, 195, 350.

12. Bendich, A. Nucleic acids and the genesis of cancer. Bull. N. Y. Acad. Med. 1961, 37, 661.

13. Diderholm, H., H. T. Fichtelius, and O. Linder. Availability time of $\mathrm{H}^{3}$ label after administration of $\mathrm{H}^{3}$ thymidine in vivo. Exp. Cell Res. 1962, 27, 431.

14. Baserga, R., and W. E. Kisieleski. Comparative study of the kinetics of cellular proliferation of normal and tumorous tissues with the use of tritiated thymidine. I. Dilution of the label and migration of labeled cells. Nat. Cancer Inst. Monogr. 1962, 28, 331.

15. Lipkin, M. and E. Deschner. Reincorporation of tritiated thymidine label into proliferating cells of the gastrointestinal tract. In preparation. 